\title{
Pengaruh Kebijakan Deviden, Profitabilitas Dan Struktur Kepemilikan Institusional Terhadap Struktur Modal Dan Nilai Perusahaan
}

\author{
Idel Waldelmi \\ Dosen Fakultas Ekonomi Universitas Lancang Kuning Pekanbaru \\ Email: iwaldelmi@gmail.com
}

\begin{abstract}
The present research was set to investigate the effect of dividend policy, profitability dan institutional ownership structure to the capital structure and company value of manufacturing companies listed at Indonesia Stock Exchange. The sample consisted of 78 manufacturing companies which were selected using a purposive sampling technique. The data source came from Indonesia Stock Exchange and ICMD (2010 - 2012) dan emittent financial data. The data were analyzed with path analysis which was applied with SPSS software, the hypotheses were tested using a t-test. The results show that (1) The significance test results of ANOVA table indicated significance value for 0.645 , where $0.645>0.05$. Thus, Ho was accepted and Ha was rejected. It means that the coefficient of regression was not significant. The conclusion was that variables X1, X2 and X3 had no effect or contribution to variable Y. (2) The significance test results of ANOVA table indicated the significance value for 0.000 , where $0.000<0.05$. Thus, Ho was rejected and Ha was accepted. It means that the coefficient of regression was significant. Thus, the conclusion was that variables Y1, X1, X2 and X3 had effects or contributions to variable Y2.
\end{abstract}

Keywords: dividend policies, profitability, institutional ownership structure, capital structure and company value

Perusahaan-perusahaan manufaktur terbuka adalah merupakan salah satu industri di BEI yang relatif berkembang dan aktif dalam perdagangan saham, seperti yang dilakukan oleh Soliha dan Taswan (2002), Dwiaji (2011), dan Teyfoer (2012). Namun demikian, pada realitasnya tidak semua perusahaan manufaktur di BEI mampu meningkatkan kemakmuran para pemegang. Hasil penelitian Teyfoer (2012) menemukan bukti hanya ada 24 perusahaan $(16,44 \%)$ dari 146 perusahaan manufaktur selama kurun waktu 2005-2009 yang berhasil meningkatkan kemakmuran para pemegang saham yang diindikasikan dengan nilai perusahaan, atau PBV lebih dari satu. Itulah sebabnya, sangat menarik sekali untuk mengetahui variabel-variabel apakah yang dapat meningkatkan nilai perusahaan. Pengumuman pembagian. Menurut Fakhruddin dan Hadianto (2001:313), "Dividend payout ratio adalah rasio antara dividen yang dibayarkan dibandingkan dengan jumlah laba bersih per lembar saham yang diperoleh perusahaan." Besarnya dividend payout ratio dijadikan ukuran oleh para investor yang hendak menanam modal pada saham di bursa efek. Hal ini dikarenakan perusahaan yang memiliki dividend payout ratio besar menunjukkan perusahaan tersebut memiliki kinerja finansial yang baik. termotivasi untuk menanam modal.

Kebijakan dividen yang diproksikan dengan variabel Dividend payout ratio (DPR) secara parsial memiliki pengaruh yang tidak signifikan terhadap nilai perusahaan manufaktur yang diproksikan dengan PBV. Hal ini sesuai dengan teori yang dikemukakan oleh Miller dan Modligiani yang menyatakan bahwa kebijakan dividen tidak mempengaruhi nilai perusahaan karena menurut mereka rasio pembayaran dividen hanyalah rincian dan tidak mempengaruhi kesejahteraan pemegang saham. Meningkatnya nilai dividen tidak selalu diikuti dengan meningkatnya nilai perusahaan. Karena nilai perusahaan ditentukan hanya oleh kemampuan perusahaan menghasilkan laba dari aset-aset perusahaan atau kebijakan investasinya. Setelah memasukkan variabel 
kontrol dalam model persamaan tidak membuat perbedaan yang signifikan pada arah koefisien kebijakan dividen terhadap nilai perusahaan. Hasil hipotesis menyatakan bahwa kebijakan dividen berpengaruh positif dan tidak signifikan terhadap nilai perusahaan. (Umi Mardiyati, Gatot Nazir Akhmad dan Ria Putri, 2010; 15).

Pada hakekatnya, perusahaan harus juga meningkatkan perolehan laba. Peningkatan laba dapat dicapai dengan jalan bekerja secara efektif dan efisien (Peppard dan Rowland, 2004:88). Dengan demikian, idealnya suatu perusahaan harus melakukan sesuatu pekerjaan yang benar dengan benar. Efektivitas memang penting, tetapi efisiensi juga tidak kalah penting, karena berkaitan erat dengan pengeluaran biaya, supaya laba perusahaan dapat ditingkatkan. Profitabilitas yang tinggi menunjukkan prospek perusahaan baik, sehingga investor akan merespon positif sinyal tersebut dan nilai perusahaan akan meningkat (Sujokodan Soebiantoro, 2007). Ada beberapa rasio yang digunakan untuk mengukur profitabilitas perusahaan, di antaranya gross profit margin yaitu perbandingan laba kotor dengan penjualan, net profit margin yaitu perbandingan laba setelah pajak dengan penjualan, return on equity yaitu perbandingan laba setelah pajak (profit after tax) dengan modal sendiri return on investment (Fakhruddin dan Hadianto, 2001:64-65).

Penelitian ini menetapkan return on investment (ROI) sebagai proksi profitabilitas didasarkan suatu pertimbangan karena ROI dapat mengukur efektifitas perusahaan dalam menghasilkan laba bersih dengan memanfaatkan aset yang dimiliki untuk menghasilkan laba tersebut, sehingga dapat menjadi indikator keberhasilan perusahaan di pemandangan investor, sebagai mana yang dilakukan Dwiaji (2011). ROI juga merupakan rasio yang terpenting di antara rasio profitabilitas yang Hasil penelitian terdahulu telah menemukan adanya pengaruh positif profitabilitas terhadap struktur modal. Paramu (2006), melakukan penelitian untuk menganalisis bagaimana karakteristik perusahaan (biaya hutang, biaya keagenan, risiko bisnis, ukuran perusahaan, kebijakan dividen, profitabilitas, kepemilikan internal dan kepemilikan eksternal) pada berbagai industri di Indonesia mempengaruhi struktur modal. Hasil penelitian ini menemukan adanya pengaruh positif dan negatif dari variable profitabilitas terhadap struktur modal untuk masing-masing sektor industri yang dianalisis. Arah pengaruh positif mengindikasikan bahwa profit pada periode sebelumnya akan cenderung meningkatkan proporsi utang dalam struktur modal pada periode sekarang. Dan sebaliknya, arah pengaruh negatif mengindikasikan bahwa profit pada periode sebelumnya akan cenderung mengurangi proporsi utang dalam struktur modal pada periode sekarang.

Profitabilitas memiliki pengaruh yang positif signifikan terhadap nilai perusahaan. Hasil uji tersebut tetap sama saat model persamaan regresi menambahkan variabel kepemilikan manajerial. Hal ini berarti semakin tinggi nilai profit yang didapat maka akan semakin tinggi nilai perusahaan. Kepemilikan Institusional adalah kepemilikan saham oleh pihak-pihak yang berbentuk seperti bank, perusahaan asuransi, dana pensiun dan institusi lainnya (Wahidahwati, 2002). Dalam penelitian ini jumlah kepemilikan institusional dihitung dengan membandingkan proporsi kepemilikan saham oleh institusi dengan jumlah saham yang beredar seluruhnya.

$$
\text { Menurut agency theory bahwa }
$$
tingkat kepemilikan yang tinggi oleh institusi dalam suatu perusahaan akan menimbulkan usaha pengawasan yang lebih besar oleh investor institusional sehingga akan dapat mengontrol manajer untuk tidak melakukan perbuatan yang tidak sejalan dengan kepentingan pemegang saham yang akhirnya dapat mengurangi agency cost. Kebijakan pendanaan atau struktur modal adalah perbandingan atau imbangan pendanaan jangka panjang perusahaan yang ditunjukkan oleh perbandingan hutang jangka panjang terhadap modal sendiri 
(Martono dan Harjito, 2008). Risiko yang makin tinggi akibat besarnya hutang cenderung akan menurunkan harga saham, tapi meningkatnya expected return yang diharapkan akan meningkatkan harga saham. Dari sini muncul konsep struktur modal optimal (optimal capital structure) yaitu struktur modal yang mengoptimalkan keseimbangan antara risiko dan pengembalian sehingga dapat memaksimumkan harga saham.

Struktur modal yang ditargetkan (target capital structure) yaitu bauran atau perpaduan dari hutang, saham preferen dan saham biasa yang dikehendaki perusahaan dalam struktur modalnya. Meskipun struktur modal yang ditargetkan akan berubah-ubah sesuai dengan perubahan kondisi perusahaan, industri dan perekonomian, pada umumnya perusahaan telah menghitung dan mempunyai pedoman untuk mencapai struktur modal tertentu. Dengan adanya struktur modal ditargetkan, setiap pembiayaan akan berpatokan pada bauran modal tersebut. Jika penggunaan hutang berada dibawah target, maka perusahaan harus mencari pinjaman. Demikian juga, jika rasio hutang telah diatas target, ada kemungkinan perusahaan harus menjual saham baru.

Nilai perusahaan merupakan persepsi investor terhadap perusahaan terbuka, yang sering dikaitkan dengan harga saham (Sujoko dan Soebiantoro, 2007). Harga saham yang tinggi membuat nilai perusahaan juga tinggi. Adapun yang dimaksud dengan harga saham di sini adalah harga yang terjadi pada saat saham diperdagangkan di pasar (Fakhruddin dan Hadianto, 2001:316), atau tepatnya disebut harga penutupan (clossing price). Optimalisasi nilai perusahaan yang merupakan tujuan perusahaan dapat dicapai melalui pelaksanaan fungsi manajemen keuangan, dimana satu keputusan keuangan yang diambil akan mempengaruhi keputusan keuangan lainnya dan berdampak pada nilai perusahaan (Fama dan French, 1998).

Pendukung dari tidak relevannya kebijakan dividen adalah Modigliani-Miller (MM). Mereka berpendapat bahwa bagaimanapun kebijakan dividen itu memang tidak mempengaruhi harga saham maupun kemakmuran pemegang saham. Lebih lanjut MM berpendapat bahwa nilai perusahaan ditentukan oleh earning power dan asset perusahaan tersebut. Dengan demikian nilai perusahaan ditentukan oleh keputusan investasi. Sementara itu keputusan apakah laba yang diperoleh akan dibagikan dalam bentuk dividen atau akan ditahan tidak mempengaruhi nilai perusahaan.

Teori ini dikemukakan oleh Myron Gordon (1959) dan John Lintner (1956) yang berpendapat bahwa ekuitas atau nilai perusahaan akan turun apabila rasio pembayaran dividen dinaikkan, karena para investor kurang yakin terhadap penerimaan keuntungan modal (capital gain) yang dihasilkan dari laba yang ditahan dibandingkan seandainya para investor menerima dividen. Gordon dan Lintner berpendapat bahwa sesungguhnya investor jauh lebih menghargai pendapatan yang diharapkan dari dividen daripada pendapatan yang diharapkan dari keuntungan modal.

Ada tiga alasan yang berkaitan dengan pajak untuk beranggapan bahwa investor mungkin lebih menyukai pembagian dividen yang rendah dari pada yang tinggi, yaitu:

1. Keuntungan modal dikenakan tarif pajak lebih rendah dari pada pendapatan dividen. Untuk itu investor yang kaya (yang memiliki sebagian besar saham) mungkin lebih suka perusahaan menahan dan menanamkan kembali laba ke dalam perusahaan. Pertumbuhan laba mungkin dianggap menghasilkan kenaikkan harga saham, dan keuntungan modal yang pajaknya rendah akan menggantikan dividen yang pajaknya tinggi.

2. Pajak atas keuntungan tidak dibayarkan sampai saham terjual, sehingga ada efek nilai waktu.

3. Jika selembar saham dimiliki oleh seseorang sampai ia meninggal, 
sama sekali tidak ada pajak keuntungan modal yang terutang. Menurut Brigham dan Gapenski (2006:629), "Profitability is the net results of a number of policies and decisions." Brigham dan Houston (dalam Mardi, 2008) juga menyatakan bahwa profitabilitas adalah hasil bersih dari serangkaian kebijakan dan keputusan dalam perusahaan.

Profitabilitas yang tinggi menunjukkan prospek perusahaan baik, sehingga investor akan merespon positif sinyal tersebut dan nilai perusahaan akan meningkat (Sujoko dan Soebiantoro, 2007). Ada beberapa rasio yang digunakan untuk mengukur profitabilitas perusahaan, di antaranya gross profit margin yaitu perbandingan laba kotor dengan penjualan, net profit margin yaitu perbandingan laba setelah pajak dengan penjualan, return on equity yaitu perbandingan laba setelah pajak (profit after tax) dengan modal sendiri, dan return on investment (Fakhruddin dan Hadianto, 2001:64-65). Penelitian ini menetapkan return on investment (ROI) sebagai proksi profitabilitas didasarkan suatu pertimbangan karena ROI dapat mengukur efektifitas perusahaan dalam menghasilkan laba bersih dengan memanfaatkan aset yang dimiliki untuk menghasilkan laba tersebut, sehingga dapat menjadi indikator keberhasilan perusahaan di pemandangan investor, sebagai mana yang dilakukan Dwiaji (2011).

$$
\text { Jensen dan Meckling }
$$

menyatakan bahwa kepemilikan institusional memiliki peranan yang sangat penting dalam meminimalisasi konflik keagenan yang terjadi antara manajer dan pemegang saham. Penelitian Smith (1996) (dalam Suranta dan Midiastuty, 2004) menunjukkan bahwa aktivitas monitoring institusi mampu mengubah struktur pengelolaan perusahaan dan mampu meningkatkan kemakmuran pemegang saham. Hal ini didukung oleh Cruthley et al., (dalam Suranta dan Midiastuty, 2004) yang menemukan bahwa monitoring yang dilakukan institusi mampu mensubstutisi biaya keagenan lain sehingga biaya keagenan menurun dan nilai perusahaan meningkat.
Teori struktur modal menjelaskan apakah ada pengaruh perubahan struktur modal terhadap nilai perusahaan, Jika keputusan investasi dan kebijakan deviden dipegang konstan. Dengan kata lain, jika perusahaan menggantikan sebagian modal sendiri dengan hutang atau sebaliknya apakah harga saham akan berubah, apabila perusahaan tidak merubah keputusankeputusan keuangan lainnya. modal ternyata nilai perusahaan berubah, maka akan diperoleh struktur modal yang terbaik. Struktur modal yang akan memaksimumkan nilai perusahaan adalah Teori Pendekatan Tradisional

Pendekatan Tradisional berpendapat akan adanya struktur modal yang optimal. Artinya Struktur Modal mempunyai pengaruh terhadap Nilai Perusahaan, dimana Struktur Modal dapat berubah-ubah agar bisa diperoleh nilai perusahaan yang optimal.

Teori Pendekatan Modigliani dan Miller Dalam kondisi tanpa pajak, Modiglini dan Miller berpendapat bahwa Struktur Modal tidak mempengaruhi nilai perusahaan. Tingkat keuntungan dan resiko usaha ( keputusan investasi) yang akan mempengaruhi nilai perusahaan (bukannya keputusan pendanaan). Juga MM Dalam teori ini berpendapat bahwa dengan memperhitungkan pajak, Struktur Modal bisa mempengaruhi Nilai Perusahaan.

Dalam kenyataan, ada hal-hal yang membuat perusahaan tidak bisa menggunakan hutang sebanyak banyaknya. Suatu hal yang terpenting adalah dengan semakin tingginya hutang, akan semakin tinggi kemungkinan kebangkrutan. Biaya kebangkrutan tersebut bisa cukup signifikan. Biaya tersebut terdiri dari 2 (dua) hal, yaitu :

a. Biaya Langsung yaitu, biaya yang dikeluarkan untuk membayar biaya administrasi, atau biaya lainnya yang sejenis.

b. Biaya Tidak Langsung yaitu, biaya yang terjadi karena dalam kondisi kebangkrutan, perusahaan lain atau pihak lain tidak mau berhubungan 
dengan perusahaan secara normal. Misalnya Suplier tidak akan mau memasok barang karena mengkwatirkan kemungkinan tidak akan membayar.

c. Biaya lain dari peningkatan hutang adalah meningkatnya biaya keagenan antara pemegang hutang dengan pemegang saham akan meningkat, karena potensi kerugian yang dialami oleh pemegang hutang akan meningkatkan pengawasan terhadap perusahaan. Pengawasan bisa dilakukan dalam bentuk biaya biaya monitoring (Persyaratan yang lebih ketat) dan bisa dalam bentuk kenaikan tingkat bunga.

Teori Trade-Off mempunyai implikasi bahwa manager akan berfikir dalam kerangka trade-off antara penghematan pajak dan biaya kebangkrutan dalam penentuan Struktur Modal.

Teori Asimetri Informasi dan Signaling. Teori ini mengatakan bahwa dalam pihak pihak yang berkaitan dengan perusahaan tidak mempunyai informasi yang sama mengenai prospek dan resiko perusahaan

Menurut Teori ini ada asimetri informasi antara manger dengan pihak luar. Manager mempunyai informasi yang lebih lengkap mengenai kondisi perusahaan dibandingan pihak luar. Signaling mengembangkan model dimana struktur modal (penggunaan hutang) merupakan signal yang disampaikan oleh manager ke pasar. Jika manager mempunyai keyakinan bahwa prospek perusahaan baik, dan karenanya ingin agar saham tersebut meningkat, ia ingin megkomunikasikan hal tersebut kepada investor. Manager bisa menggunakan hutang lebih banyak sebagai signal yang lebih credible. Karena perusahaan yang meningkatkan hutang bisa dipandang sebagai perusahaan yang yakin dengan prospek perusahaan di masa mendatang.

Menurut pendekatan ini, struktur modal disusun untuk mengurangi konflik antar berbagai kelompok kepentingan. Konflik antara pemegang saham dengan manager adalah konsep free-cash flow. Teori ini berangkat dari teori organisasi industri dan relatif baru, dibandingkan dengan teori lainnya. Ada dua kategori dalam pendekatan ini, yaitu Strategi dan Menjelaskan hubungan antara Struktur Modal dengan karakteristik produk atau input.

Konteks atas Pengendalian Perusahaan

Beberapa penemuan pendekatan ini adalah perusahaan yang menjadi target (dalam pengambilalihan) akan meningkatkan tingkat hutangnya, berhubungan dengan kemungkinan sukses tender offer (penawaran terbuka pada proses pengamalihan usaha

\section{METODE}

Penelitian yang dilakukan termasuk jenis penelitian penjelasan atau exsplanatory research. Penelitian. Populasi dalam penelitian ini adalah Seluruh perusahaan dalam kelompok industri manufaktur yang telah go public sesuai dengan klasifikasi dalam Indonesian Capital Market Directory (ICMD). Pertimbangan memilih perusahaan dalam kelompok industri manufaktur adalah: a) Jumlah perusahaan yang termasuk dalam kelompok manufaktur yang terdaftar di BEI relatif banyak, sehingga memungkinkan peneliti untuk memperoleh data yang lebih banyak. b) Perusahaan dalam kelompok industri manufaktur relatif lebih aktif membagikan dividen dibandingkan kelompok perusahaan lainnya. Proses dalam menentukan sampel menggunakan metode multy stage sampling yang dikemukakan oleh Daniel \& Terel (1989).

Data dan informasi yang dibutuhkan diperoleh dari : Laporan keuangan Emiten yang dipublikasikan, seperti laporan harian harga saham, laporan keuangan emiten, informasi dari Koran, majalah dan jurnaljurnal yang berhubungan dengan masalah yang diteliti. Data juga diperoleh melalui kunjungan ke website-website yang memberikan informasi saham seperti: Web http://www.idx.co.id; Web site Bapepam http://www.bapepamlk.depkeu.go.id; Web 
site BI http://www.bi.go.id ; Web site Indonesia Interactive http://www.investorindonesia.com; Web site Stock Watch http://www.e-bursa.com. Studi kepustakaan, yaitu dengan membaca dan mempelajari serta mendalami berbagai literatur yang berkaitan dengan masalah yang diteliti. Studi kepustakaan dilakukan untuk mengetahui lebih dalam dan membandingkan antara teori dengan kenyataan di lapangan. Model path analysis digunakan untuk menganalisis pola hubungan antar variabel dengan tujuan untuk mengetahui pengaruh langsung maupun tidak langsung seperangkat variabel bebas (eksogen) terhadap variabel terikat (endogen) (Riduwan dan Engkos, 2008).

\section{HASIL}

Uji $F$ digunakan untuk mengetahui apakah variabel-variabel independen secara simultan berpengaruh signifikan terhadap variabel dependen. Derajat kepercayaan yang digunakan adalah 0,05. Apabila nilai $F$ hasil perhitungan lebih besar daripada nilai $F$ menurut tabel maka hipotesis alternatif, yang menyatakan bahwa semua variabel independen secara simultan berpengaruh signifikan terhadap variabel dependen.

Uji $\mathrm{t}$ digunakan untuk mengetahui apakah variabel-variabel independen secara parsial berpengaruh nyata atau tidak terhadap variabel dependen. Derajat signifikansi yang digunakan adalah 0,05. Apabila nilai signifikan lebih kecil dari derajat kepercayaan maka kita menerima hipotesis alternatif, yang menyatakan bahwa suatu variabel independen secara parsial mempengaruhi variabel dependen.

Dari table tersebut terlihat bahwa nilai $\mathrm{R}^{2}$ sebesar 0.022 , artinya pengaruh variable $\mathrm{X} 1, \mathrm{X} 2$ dan $\mathrm{X} 3$ terhadap variable $\mathrm{Y}$ secara simultan sebesar $2,2 \%$

\begin{tabular}{|c|c|c|c|c|c|c|}
\hline \multicolumn{7}{|c|}{ ANOVAB } \\
\hline Model & & $\begin{array}{l}\text { Sum of } \\
\text { Squares }\end{array}$ & $d f$ & Mean Square & $\mathrm{F}$ & Sig. \\
\hline \multirow[t]{3}{*}{1} & Regression & 4.408 & 3 & 1.469 & .556 & $.645^{\mathrm{a}}$ \\
\hline & Residual & 195.411 & 74 & 2.641 & & \\
\hline & Total & 199.819 & 77 & & & \\
\hline
\end{tabular}

Hasil uji signifikansi table ANOVA menunjukkan nilai Sig. sebesar 0.645, dimana $0.645>0.05$, dengan demikian Ho diterima dan tolak $\mathrm{Ha}$, artinya koefisien regresi adalah tidttidak signifikan. Dengan demikian dapat di simpulkan bahwa variable $\mathrm{X} 1, \mathrm{X} 2$ dan $\mathrm{X} 3$ tidak mempunyai pengaruh atau kontribusi terhadap variable Y.

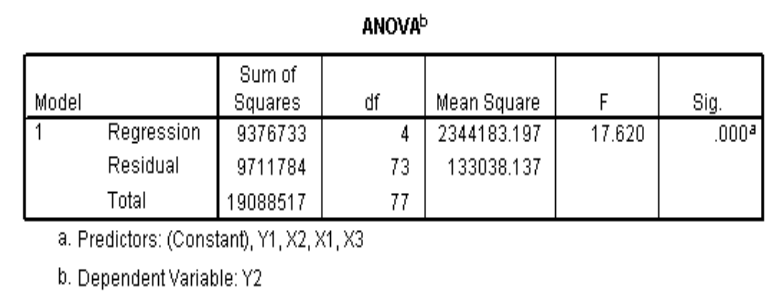

Dari table tersebut terlihat bahwa nilai $\mathrm{R}^{2}$ sebesar 0.491 , artinya pengaruh variable $\mathrm{Y} 1, \mathrm{X} 1, \mathrm{X} 2$ dan X3 terhadap variable Y2 secara simultan sebesar 49.10\%. Hasil uji signifikansi table ANOVA menunjukkan nilai Sig. sebesar 0.000 , dimana $0.000<$ 0.05, dengan demikian Ho ditolak dan terima $\mathrm{Ha}$, artinya koefisien regresi adalah signifikan.

\begin{tabular}{|l|r|r|r|r|r|}
\hline ANOVA & \\
\hline Model & Sum of Squares & df & Mean Square & F & Sig. \\
\hline 1 Regression & 1.557 & 2 & .779 & .094 & $.911^{\text {a }}$ \\
Residual & 623.253 & 75 & 8.310 & & \\
Total & 624.811 & 77 & & & \\
\hline
\end{tabular}

ictors: (Constant), Struktur Kepemilik, Profitabilitas

b. Dependent Variable: Kebjk Deviden

Hasil Uji signifikan table ANOVA menunjukkan nilai Sig. sebesar 0.911 dimana 0.911>0.05 dengan demikian Ho diterima dan ditolak $\mathrm{Ha}$, artinya koefisien regresi adalah tidak sinifikan. Dengan demikian dapat di simpulkan bahwa variable X2 dan X3 tidak signifikan atau kontribusi terhadap variable X1.

\section{PEMBAHASAN}

Hasil uji signifikansi table ANOVA menunjukkan nilai Sig. sebesar 0.645, dimana $0.645>0.05$, dengan demikian Ho diterima dan tolak $\mathrm{Ha}$, artinya koefisien regresi adalah tidak signifikan. Dengan demikian dapat di simpulkan bahwa variable $\mathrm{X} 1, \mathrm{X} 2$ dan $\mathrm{X} 3$ tidak mempunyai 
pengaruh atau kontribusi terhadap variable Y. Hasil uji signifikansi table ANOVA menunjukkan nilai Sig. sebesar 0.000, dimana $0.000<0.05$, dengan demikian Ho ditolak dan terima $\mathrm{Ha}$, artinya koefisien regresi adalah signifikan. Dengan demikian dapat di simpulkan bahwa variable $\mathrm{Y} 1, \mathrm{X} 1$, $\mathrm{X} 2$ dan $\mathrm{X} 3$ mempunyai pengaruh atau kontribusi terhadap variable Y2. Hasil Uji signifikan table ANOVA menunjukkan nilai Sig. sebesar 0.911 dimana 0.911>0.05 dengan demikian Ho diterima dan ditolak Ha, artinya koefisien regresi adalah tidak sinifikan. Dengan demikian dapat di simpulkan bahwa variable X2 dan X3 tidak signifikan atau kontribusi terhadap variable $\mathrm{X} 1$.

\section{SIMPULAN}

Hasil penelitian ini menunjukkan Secara simultan kepemilikan, kebijakan dividend dan profitabiltas secara bersama - sama tidak berpengaruh terhadap struktur modal. Akan tetapi pengaruhnya kecil yakni sebesar $2,2 \%$. Hal ini dapat dilihat dari hasil sig > 0,05 yakni sebesar 0,646>0,05. Pada struktur persamaan 2, secara simultan kepemilikan, kebijakan dividend dan profitabiltas dan struktur modal secara bersama tidak berpengaruh . Dan hasilnya secara bersama sama tidak berpengaruh, hal ini dapat dilihat dari hasil sig < 0,05 yakni sebesar 0,000 < 0,05. Variable kebijakan deviden, profitabilitas dan struktur kepemilikan Institusional memiliki kontribusi terhadap $\mathrm{Y}_{2}$. Nilai $\mathrm{t}$ positif menunjukkan bahwa variabel kebijakan deviden, profitabilitas dan struktur kepemilikan Institusional mempunyai hubungan yang searah dengan $\mathrm{Y}_{2}$. Jadi dapat disimpulkan kebijakan deviden, profitabilitas dan Struktur Kepemilikan Institusional memiliki pengaruh signifikan terhadap Nilai Perusahaan.

\section{DAFTAR RUJUKAN}

Amirya, Mirna dan Atmini Sari. 2007. Faktor-faktor yang mempengaruhi nilai perusahaan yang dimediasi oleh leverage sebagai variable intervening : sebuah perspektif Pecking Order
Theory. The 1 Accounting conference faculty of economic Universitas Indonesia, Depok 7-9 November 2007.

Aryati, Titik dan Hekinus Manao. 2000, Rasio Keuangan sebagai prediktor bank bermasalah di Indonesia. Jurnal Simposium Nasional Akuntansi III, September 2000.Ikatan Akuntansi Indonesia.

Arthesa, Ade dan Edia Handiman. 2006, Bank dan Lembaga Keuangan Bukan Bank, Jakarta, PT. Indeks Kelompok Gramedia.

Afzal, Arie dan Abdul Rohman, 2012. Pengaruh Keputusan Investasi, Keputusan Pendanaan, dan Kebijakan Deviden Terhadap Nilai Perusahaan, Diponegoro Journal of Accounting, Vol. 1, No. 2.

Analisa, Yangs. (2011). Pengaruh Ukuran Perusahaan, Leverage, Profitabilitas dan Kebijakan Deviden Terhadap Nilai Perusahaan (Studi Pada Perusahaan Manufaktur Yang Terdaftar Di Bursa Efek Indonesia Tahun 2006-2008). Skripsi Akuntansi Fakultas Ekonomi Universitas Diponegoro

Brigham, Eugene F. Dan Joul F Houston. 2001. Manajemen Keuangan. Jakarta : Erlangga.

Bringham, E.F. dan Gapenski, Louis C., (1996). Intermediate financial management, $5^{\text {th }}$ edition, Sea Harbor Drive: The Dryden Press.

Badan Sertifikasi Manajemen Risiko. 2008, Sertifikasi Manajemen Risiko Tingkat 1, Jakarta.

Bank Indonesia. 2008, Laporan Publikasi Bank Indonesia 2007. Jakarta.

Damayanti, Susana dan Fatchan Achayani. 2006. Analisis Pengaruh Investasi, 
Likuiditas, Profitabilitas, Pertumbuhan Perusahaan dan Ukuran Perusahaan Terhadap Kebijakan Deviden Payout Ratio (Studi Empiris pada Perusahaan Manufaktur yang Terdaftar di BEJ). Jurnal Akuntansi dan Keuangan. Vol. 5, No. 1, April 2006, hal. 5162.Departemen Keuangan. 1990, Surat Keputusan Menteri Keuangan RI No.792, tahun 1990, tentang Perbankan.

Febryani, Anita dan Rahadian Zulfadin. 2003, Analisis Kinerja Bank Devisa dan Bank Non Devisa di Indonesia, Kajian Ekonomi dan Keuangan Volume 7 No.4.

Ghozali, Imam. 2005, Aplikasi Analisis Multivariate Dengan Program SPSS, Undip

Gilbert, R Alton, Andrew P. Meyer dan Mark D.Vaughan. 2000, The Role of CAMEL Downgrade Model in Bank Surveillance, working paper

Gitman, J. Lawrence. 2000, Principles of Managerial Finance, Ninth Edition. San Diego State University.

Hair, Jr., Joseph, F., Rolph E., Anderson Ronald., L. Taatham and William C., Black. 1992, Multivariate Data Analysis with Readings ; (Third Eds), New York, McMillan Publishing Company.

Indra, Zubaidi A, 2006, Faktor-faktor Fundamental Keuangan Yang Mempengaruhi Risiko Saham, Jurnal Bisnis dan Manajemen Vol 2,No.3, Mei.

Indriastuti, Dorothea R.,2001. Analisis Pengaruh Faktor-faktor Fundamental Terhadap Beta Saham (Studi kasus di Bursa Efek Jakarta : Perbandingan periode sebelum dan selama krisis),Prespektif, Vol.6, No. 1, Juni.
Itan, Iskandar, 2003, Pengaruh Kinerja Keuangan Perusahaan Terhadap Harga Saham Pada Kelompok Saham LQ45 Di Bursa Efek Jakarta, Thesis Program Magister Manajemen Program Pasca Sarjana Universitas Riau, Pekanbaru.

Ikatan Akuntan Indonesia, 2004, Standar Akuntansi Keuangan, Salemba Empat, Jakarta.

Ikatan Akuntansi Indonesia. 1995, Standar Akuntansi Indonesia, Jakarta, Lembaga Penerbit Salemba Empat.

Jordan, John S dan Eric S. Rosengren. 2002, Economic Cycles and Bank Health, Journal of Financial Intermediation.

Jaffe, J and Mandelker, G ,1976, The Fisher Effect for Risk Asset : An Emperical Investigation, Journal of Finance, Vol 31, No.2, May.

Jones, Charles P, 1996, Investments,: Analysis and Management, Fifth Edition, John Willey \& Son .

--------, 1998. Investment. Sixth Edition. John Wiley \& Sons.

Kuncoro, Mudrajat (2002). Metode Kuantitatif: Teori dan Aplikasi Untuk Bisnis dan Ekonomi, Edisi Pertama, UPP AMP YKPN, Yogyakarta

Kennedy J.S.P. 2003. Analisis Pengaruh dari Return on Asset, Return on Equity, Earnings PerShare, Profit Margin, Asset Turnover, Rasio Leverage dan Debt to Equity Ratio terhadap Return Saham (Studi terhadap Saham-saham yang Termasuk dalam LQ-45 di BEJ Tahun 2001), Tesis tidak dipublikasikan, Program Pascasarjana Universitas Indonesia, Jakarta. 
Keown, Arthur J, Martin, Jhon D, Patty, J William and David F Scott JR ,2001, Basic Financial Management, 7th New York, Prentice Hall, Inc.

--------- ,1999, Dasar-Dasar Manajemen Keuangan, Edisi Ketujuh Salemba Empat, Jakarta.

Kountur, Ronny. 2003, Metode Penelitian untuk Penulisan Skripsi dan Tesis, PPM, Jakarta

Kuncoro, Mudrajad dan Suhardjono. 2002, Manajemen Perbankan. Teori dan Aplikasi. Edisi Pertama. BPFE. Yogyakarta.

Keown, Arthur J., Scott, David F., Martin, John D., dan Petty, Jay W. 1999. Dasar Dasar Manajemen Keuangan, Salemba Empat, Jakarta.

Martono. 2002, Bank dan Lembaga Keuangan Lain, Yogyakarta, Ekonisia

Martalina, Lifessy. 2011. Pengaruh Profitabilitas dan Ukuran Perusahaan Terhadap Nilai Perusahaan Dengan Struktur Modal Sebagai Variabel Intervening. Skripsi Akuntansi Fakultas Ekonomi Universitas Negeri Padang.

Munawir, S. (1988). Analisa Laporan Keuangan, Edisi Ketiga, Penerbit Liberty, Yogyakarta.

Martono, Harjito Agus D. (2005). Manajemen Keuangan, Edisi Kelima, Penerbit Ekonesia, Kampus Fakultas Ekonomi UII, Jogyakarta.

Nuratni, Ratna (2006),Pengaruh Faktorfaktor Fundamental Terhadap Harga Saham pada Industri Perbankan di Bursa Efek Jakarta, Thesis Program Magister Manajemen Program Pasca Sarjana Universitas Riau, Pekanbaru

Nayasyah, Syahid (2000). Analisis Pengaruh Beberapa Faktor Fundamental dan Risiko Sistematik terhadap return saham, Jurnal ekonomi dan Bisnis, Vol 15 No.3 Hal. 294-312.

Nizam, Javed. 1998, Banking Failures in Developing Countries : An Auditor's Perspective, International Journal of Government Auditing. January, 1998.

Putra, Bitona Chandra (2005). Analisa Pengaruh EPS dan Tingkat Bunga Terhadap Harga Saham sektor Telekomunikasi di Bursa Efek Jakarta, Skripsi Fakultas Ekonomi Manajemen Unifersitas Taruma Negara, Jakarta

Qurriyani, Nuzulul. 2000, Indikasi Potensial Menuju Bank Survival Melalui Analisis Rasio Keuangan : Model Regresi Logistik Trikotomi. Jurnal Simposium Nasional Akuntansi III. Ikatan Akuntansi Indonesia, September 2000.

Riayanto, Bambang (1995). Dasar-dasar Pembelanjaan Perusahaan, Edisi Keempat, BPFE, Yogyakarta.

Republik Indonesia. Undang-Undang Nomor 10 Tahun 1998 tentang Perubahan Undang-Undang No.7 tahun 1992 tentang Perbankan, Jakarta

Retnadi, Djoko. 2006, Memilih Bank yang Sehat, Kenali Kinerja dan Pelayanannya, PT. Elex Media Komputindo Kolompok Gramedia, Jakarta

Sudarsi, Sri. 2002. 'Analisis Faktor-Faktor Yang Mempengaruhi Devident Payout Ratio pada Industri Perbankan yang Listed Di Bursa Efek Jakarta (BEJ)'. Jurnal Bisnis dan Ekonomi. Vol.9, No.1, Maret. Hal. 76-88.

Sakhanala, Arya. 2006, Hubungan Tingkat Risiko Bank dengan Tingkat Profitabilitas, dan Pengaruhnya terhadap Harga Per Lembar Saham 
untuk Bank Umum Nasional yang telah Go Publis, tesis, Program Pasca Sarjana, Universitas Airlangga, Surabaya.

Sugiyono. 2002, Statistik untuk Penelitian, CV. Alfabeta, Bandung

Sukowati, Enny. 2006, Analisis Pengaruh CAR, NPL, NIM, BOPO dan LDR terhadap Profitabilitas (ROA \& ROE) Bank Umum (Studi Kasus terhadap 40 Bank Umum) . tesis : Program Pasca Sarjana Universitas Gunadarma, Jakarta.

Surakhmad, Winarno. 1994, Pengantar Penelitian Ilmiah, Bandung

Surat Keputusan Bank Indonesia No.6/10/PBI/2004, tanggal 12 April 2004 perihal Sistem Penilaian Tingkat Kesehatan Bank Umum.

Surat Keputusan Bank Indonesia No.6/23/DPNP, tanggal 31 Mei 2004 perihal Sistem Penilaian Tingkat Kesehatan Bank Umum.
Surat Keputusan Bank Indonesia No.8/2/PBI/2006, tanggal 30 Januari 2006 perihal Perubahan atas Peraturan Bank Indonesia nomor 7/2/PBI/2005 Tentang Penilaian Kualitas Aktiva Bank Umum.

Susilo, Y. Sri. dkk. 2000, Bank dan Lembaga Keuangan Lain, Salemba Empat, Jakarta

Undang-undang Republik Indonesia No.10, 1998, tentang Perubahan UndangUndang Republik Indonesia No.7 tahun 1992 tentang Perbankan, Jakarta

Zainah, Neneng. 2005, Pengaruh rasio CAR, LDR,NPL,NIM dan BOPO terhadap Profitabilitas Bank Umum di Indonesia periode 2002 - 2003, tesis, Program Pasca Sarjana, Universitas Indonesia. 